\title{
MIGRATIONS OF POPULATION TO RURAL AREAS AS SUBURBANIZATION DEVELOPMENT FACTOR (SUB-URBAN AREAS) IN GÓRNOŚLĄSKO-ZAGLĘBIOWSKA METROPOLIS.
}

DOI: http://dx.doi.org/10.18509/GBP.2018.37

UDC: $314.15: 316.334 .55(438)$

\author{
Marlena Dyszy \\ Elżbieta Zuzańska-Żyśko
}

University of Silesia, Faculty of Earth Sciences, Department Economic Geography, Poland

\begin{abstract}
The purpose of the article is to indicate the directions and tendencies of population migrations in the selected municipalities of the metropolitan area of GórnośląskoZagłębiowska Metropolis in the south of Poland. The inflow and outflow of population in the period of 2002-2015 and commuting in 2011 were analysed. The examined municipalities are subject to suburbanization, whereas their new habitants originate from various cities of the polycentric core. The aforementioned leads to urban sprawl and the development of dwelling function (residential) in the metropolitan area. Suburbanization predominantly occurs in the municipalities to the north of the core. In turn, commuting exhibits strong interrelations with various subcentres of the metropolis.
\end{abstract}

Key words: migration, suburbanization, rural area, polycentric metropolitan area, emigration, rural communities, immigration, migration balance.

\section{INTRODUCTION}

Post-socialist areas experienced numerous transformations in socio-economic fields, which has resulted in certain consequences in urban and sub-urban space [6], [19], [10], [7], [11], [5], [25], [27]. Altogether with the transformation of system, suburbanization processes intensified, particularly after 1990 [20], [8], [9], [23]. Suburbanization occurs if the population of peripheries, i.e. sub-urban area, grows more rapidly than in case of central areas. Populations migrate from large clusters to outskirts, outside of city limits.

The transformations in sub-urban area lead to the formation of new housing estates, service-based companies and industrial plants. New socio-economic interrelations, in turn, influence the occurrence and development of vast urban areas, daily urban systems, with intensified commuting to workplaces and metropolitan regions [30].

The purpose of the article is to indicate the directions and tendencies of population migrations in the selected municipalities of the metropolitan area of GórnośląskoZagłębiowska Metropolis in the south of Poland.

For the most part of the post-war period, rural areas in Poland could be characterized by an outflow of population, nonetheless these losses were compensated with a relatively high rate of birth. Due to the reason mentioned above, the number of rural dwellers levelled off. Migration processes started to play a major role in the spatial diversification of the number of rural inhabitants [1], which since the nineties of the twentieth century has been increasing gradually in Poland. In 2005, 15.2 million of Poles were inhabiting villages [2], whereas in 1991-2010, over 2 million of the inhabitants of cities emigrated to villages. Migrations hitherto: village-city and city-city, have been supplemented with 
the direction of city-village, which gives evidence of the advanced process of urbanization, and even or metropolization characteristic for highly developed countries of the world. This trend intensified towards the end of the nineties, and since $2000 \mathrm{a}$ positive migration balance for the entire rural areas can be seen [21], principally due to the positive migration balance. An outflow from metropolitan areas to their outskirts was distinguishable [24]. The increase of population inflow manifested itself in rural municipalities located in the suburban areas of major cities, while - to a lesser extent in the suburban areas of medium to small cities [29], [14], [16]. This phenomenon occurs the most evidently and intensely in the suburban areas of urban complexes and metropolitan areas [31]. The highest intensity of these processes occurs in rural municipalities which are located in the direct vicinity of central cities [4], as well as in the areas along major passageways.

\section{METHODOLOGY AND STUDY AREA}

The periodic scope of the elaboration focuses on 2002 - 2015. The spatial scope of the elaboration takes into account eight rural municipalities of Silesia. These are the units located in the external zone of Górnośląsko-Zagłębiowska Metropolis located in the south of Poland. It was constituted by act in 2017. Heretofore it is the only legally and lawfully established metropolitan area in the country. The core is composed of 13 major county cities and 28 other locations, including small towns and villages. The municipalities under study are located in different counties, and simultaneously in the areas of interaction of other core cities. It results from the fact that the metropolitan area has industrial genesis and originates from a conurbation, similarly to Ruhrgebiet in Germany. Municipalities chosen for the study:

- Bobrowniki (11.8 thousand) and Psary (11.8 thousand) in Będziński county,

- Śwerklaniec (11.8 thousand) and Zbrosławice (15.8 thousand) in Tarnogórski county,

- Chełm Śląski (6.1 thousand) in Bieruńsko-Lędziński county,

- Kobiór (4.9 thousand) in Pszczyński county,

- Wyry (7.8 thousand) in Mikołowski county,

- Gierałtowice (11.7 thousand) in Gliwicki county (Fig. 1).

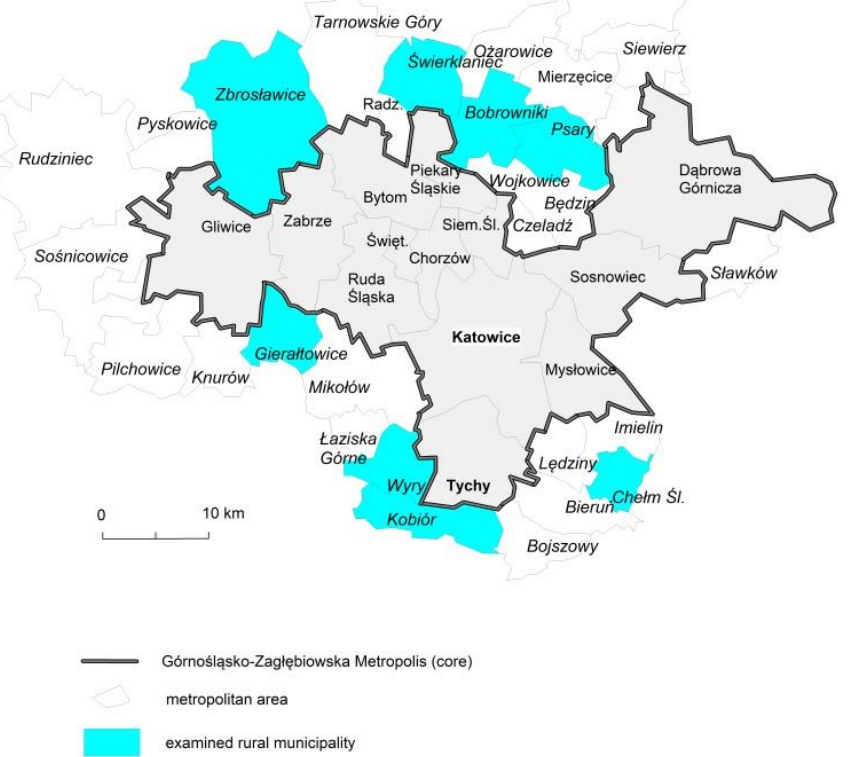

Figure 1. Municipalities studies in Górnośląsko-Zagłębiowska Metropolis. 
Statistical data originate from Local Data Bank (years 2002 - 2015). The number of inhabitants, internal migrations, inflows, outflows and population balance were taken into consideration. In order to compare the areas of examination, the data were elaborated on the basis of basic demographic indicators. On the basis of GIS maps, the radius of major migrations of the municipalities studied was determined, hence the area of spatial integration of migrations, as well as the direction thereof. In terms of commuting, the data of 2011 were used. The selection of this year is based on the fact that Polish statistics does not possess systematic databases concerning commuting.

\section{FINDINGS AND DISCUSSION}

Silesia is the most densely populated region in Poland. 71 cities, including 12 of over 100 thousand inhabitants, are located here, totalling 4,559.2 inhabitants. $77 \%$ of the population resides in cities (3.2 million), whereas 2.2 million inhabitants dwell in the metropolitan area. The region faces serious problems of depopulation and ageing [15]. It shall be pointed out that the major cities of the central part of Silesia exhibit a major decrease of population. This process has manifested itself primarily in some core cities of the metropolis: Siemianowice Śląskie, Zabrze, Sosnowiec, Bytom, Świętochłowice and Katowice, Ruda Śląska, Chorzów and Gliwice [18]. During 1999 - 2011, the highest negative migration balance occurred in the municipalities of Gliwice, Katowice and Rybnik sub-regions. Of different character are the population trends of the examined area, where the quantity of inhabitants increases. In 1999 - 2008, the highest migration balance was recorded in the rural municipalities of Bielsko region, as well as in the background of Rybnik and Katowice conurbations, not to mention Częstochowa agglomeration [13]. In 2002 - 2015, the area under study experienced an increase of the population, due to a positive migration balance, of 8,191 people. For the entire area the migration balance came up to $7.47 \%$. Of the highest migration balance as per 1,000 inhabitants were the municipalities located to the north of Katowice conurbation, i.e., Bobrowniki, Psary, Świerklaniec, as well as the municipalities located in the southern and western part, with an exception of Wyry. Of the lowest migration balance in the temporal scope of the study was Zbrosławice, whereas the highest - Wyry (Table 1).

Table 1. The migration balance for selected rural municipalities of the Silesia Province in the years $2002-2015$.

\begin{tabular}{|c|c|c|c|c|}
\hline Municipality & County & $\begin{array}{c}\text { Population } \\
\text { in municipalities } \\
\text { in 2015 }\end{array}$ & $\begin{array}{c}\text { Total migration } \\
\text { balance }\end{array}$ & $\begin{array}{c}\text { Migration balance } \\
\text { as per 1,000 } \\
\text { inhabitants }\end{array}$ \\
\hline Bobrowniki & Będziński & 11881 & 1418 & 8.8 \\
\hline Psary & Będziński & 11877 & 1592 & 9.9 \\
\hline Świerklaniec & Tarnogórski & 11846 & 1279 & 8.1 \\
\hline Zbrosławice & Tarnogórski & 15858 & 509 & 2.3 \\
\hline Chełm Śląski & Bieruńsko-lędziński & 6130 & 528 & 6.5 \\
\hline Kobiór & Pszczyński & 4918 & 319 & 4.8 \\
\hline Wyry & Mikołowski & 7837 & 1511 & 15.8 \\
\hline Gierałtowice & Gliwicki & 11758 & 1035 & 6.7 \\
\hline \multicolumn{2}{r}{} & 82105 & 8191 & 7.5 \\
\hline
\end{tabular}

Source: author's elaboration on the basis of data of Central Statistical Office.

The positive migration balance proves that the examined municipalities are undergoing suburbanization processes. They occurred the earliest in Bobrowniki, Psary, Świerklaniec, Wyry and Gierałtowice. In 2005, suburbanization started in Chełm Śląski, 
followed by Kobibór in 2012. Suburbanization occurred at the latest in Zbrosławice, as late as in 2014. To sum up, suburbanization started at the earliest in the municipalities located in the north from the core of Górnośląsko-Zagłębiowska Metropolis.

The examined area experienced an inflow of 19.6 thousand new inhabitants in 2002 2015 , on average 175 people per year for a single municipality. The migration trend upholds its positive tendency. Zbrosławice experience the highest inflow of people: 3,617 , even though the process of suburbanization started as late as in 2014. The second and third municipalities were Bobrowniki and Świerklaniec (exceeding 3000 people). In the range of 2000 to 3000 people, Psary $(2,919)$, Gierałtowice $(2,400)$ and Wyry $(2,361)$ can be mentioned. Less inhabitants came to Chełm Śląski - 1,235 people. Among all of the municipalities studies, Kobiór experienced the lowest inflow of inhabitants -978 people.

Of all of the migrants, over $90 \%$ were inhabitants originating from rural areas. The highest rate of inflow of city dwellers occurred in Zbrosławice, where - in turn - the inflow of village dwellers was $4 \%$. The biggest inflow of population from rural areas took place in Bobrowniki (7\%), whereas the smallest - in Wyry (1\%). In the entire area under examination, the lowest factor of inflow occurred in 2004 (14.3\%o), whereas the highest in 2013 (21.8\%o). It shall be highlighted here that the average factor of inflow in Poland, from cities to villages took place in 2015 (7.9\%o), in 1991 - 2000 the figure was 6.4\%o, whereas in 2001-2010 - 8,9\%o [2]. In 2015 the migration balance is negative, amounting to $-0,4 \%$.

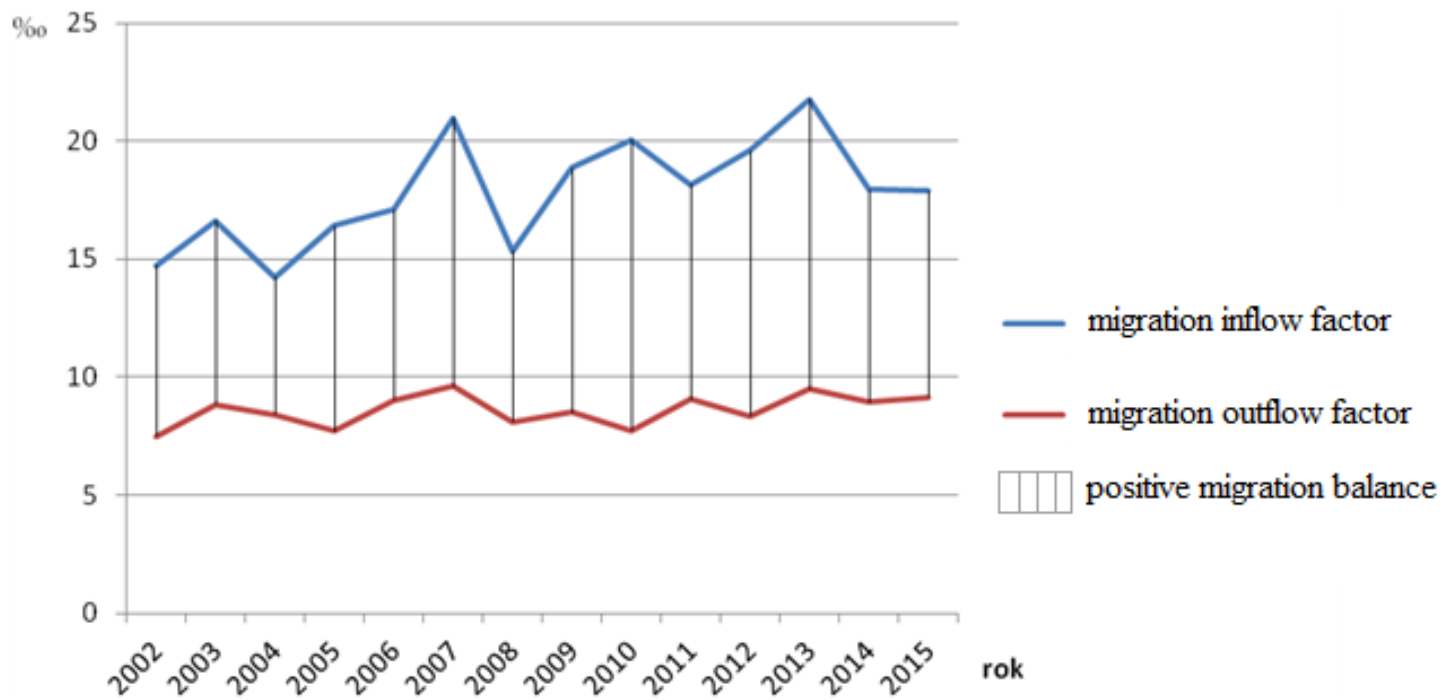

Figure 2. Inflow and outflow of population in the area of selected rural municipalities of the Silesia Province in the years $2002-2015$.

The examined area has also been experiencing the outflow of population. In $2002-2015$ the total of 9,446 inhabitants left the area. The lowest factor of migration outflow was recorded in $2002-7.5 \%$, whereas the highest in $2013-9.5 \%$. The inhabitants of the rural municipalities under study migrated predominantly to the surrounding urban areas. Taking into consideration the inflows and outflows as per 1,000 inhabitants, major differences in the studied group of municipalities can be noticed. The highest inflow of population occurs in Wyry - 24.6 per 1,000 inhabitants, where most people migrated from 
rural areas. The municipality of Bobrowniki experienced the biggest inflow of former inhabitants of villages (per 1,000 inhabitants).

After the analysis of the entire area, one may come to a conclusion that the new inhabitants of rural areas are fundamentally the residents of Silesia, mainly from the core cities of Górnośląsko-Zagłębiowska Metropolis.

On a yearly basis, Bobrowniki experienced the inflow of 8.8 people per 1,000 inhabitants. In total, in 2002 - 2015, 3,068 new inhabitants appeared to the municipality, out of which 2,585 from urban areas and 187 from rural areas, mainly from Silesia. The migration factor fluctuated from 3.3\% in 2004 to $13.6 \%$ in 2010. Most of the migrants originated from the urban areas located in the vicinity or within $16 \mathrm{~km}$ : Piekary Śląskie, Bytom and Siemianowice Śląskie. These cities are located within the distance of $8 \mathrm{~km}$. The municipality of Bobrowniki is well connected with the aforementioned cities in terms of commuting, both in relation to public transport and road network. Until 2010, the largest proportion of migrants to a given municipality originated from Katowice, Sosnowiec, Będzin and Wojkowice. In Bobrowniki the inflow of new inhabitants occurs more intensively that the outflow, which gives evidence of the occurring suburbanization process.

Similar migration tendencies may be observed in Psary inhabited by 11,877 people in 2015. The migration factor fluctuated from $8.9 \%$ in 2002 to $6.2 \%$ in 2015 , with a peak of $13.4 \%$ in 2013. In 2002 - 2015 the total of 2,919 people migrated to the municipality, fundamentally from urban areas, whereas the migration factor came up to $9.9 \%$. The biggest intensification was experienced in 2013 - 22.3\%o. The inflow of people was encompassed by an isochrone of $15 \mathrm{~km}$. Będzin was the place of origin of most new inhabitants ( 817 people), which equals to $6.9 \%$ of inhabitants. A significant participation of migrants were the inhabitants of major cities - the core of the metropolis: Sosnowiec and Dąbrowa Górnicza. The amount of people from Czeladź increased in 2012 and 2013. Convenient road connections (S86 state road) facilitate the migration of population.

The municipality of Świerklaniec and Zbrosławice are located in Tarnogórski county, in the northern part of the metropolitan area. Świerklaniec is one of the municipalities of a steady increase of migration balance, which translates into an increase of its inhabitants. Initially thee has been a slight increase, on the level of $2.5 \%$, nevertheless it was increasing to reach the value of $15.6 \%$ in 2010 . In the investigated period, the total of 3,018 new inhabitants migrated to the area, out of which 2,677 from urban areas and only 52 people from rural areas. Most of them arrived from Bytom (772) and Tarnowskie Góry (535), since 2005 - from Piekary Śląskie, whereas in 2004 and 2013 from Radzionków. The biggest number of new dwellers came to Świerklaniec from the surrounding areas located within the maximum distance of $15 \mathrm{~km}$. New inhabitants constitute as much as $25.5 \%$ of the population of Świerklaniec.

In turn, in Zbrosławice the migration balance of 2002 - 2015 fluctuated from a positive balance to a negative one. The highest migration dynamics may be observed since 2014 . As many as 3,617 new settlers arrived in the examined period, which is the highest inflow among all discussed rural municipalities. 2,942 people arrived from urban areas (18.6\%), whereas $131(0.8 \%)$ from rural ones. In general, all of the migrants constituted $23 \%$ of the population of Zbrosławice. The dominant group was composed of former inhabitants of Gliwice and Zabrze, to a lesser extent from Tarnowskie Góry and Bytom.

The municipality of Chełm Śląski is located in Bieruńsko-Lędziński county, to the south of the core of Górnośląsko-Zagłębiowska Metropolis. In 2002 - 2015 the migration balance reached positive values, except for 2004. The trend of migration balance is on a 
steady level. In the period of 14 years, 1,235 new residents appeared, primarily from urban areas. Among all of the areas under study, Chełm Śląski occupies the second place after Kobibór, with the lowest migration inflow in terms of size, whereas as per 1,000 inhabitants the inflow fluctuated around $10.1 \%$ in 2004, to reach $20.1 \%$ in 2013 . The dominant group was composed of the former inhabitants of Mysłowice, Katowice and Tychy. An increase of inhabitants originating from the adjoining small cities of Bierun and Lędziny can be observed. Migrations from larger cities give evidence of suburbanization of the municipality of Chełm Śląski which is located in the area of influence of fire core cities and two small towns.

As compared with the remaining rural municipalities under study, Kobiór experienced in 2002 - 2015 slight migrations. There are 978 new residents, primarily from urban areas. The migration factor decreases and was on the level of 25\% in 2004 and 8.4\%o in 2011. The dominant group of migrants is composed of the former inhabitants of Tychy, Pszczyna and Katowice. Of all of the discussed municipalities, solely and exclusively in Kobiór the inflow of new habitants exhibits a downward trend, as compared to the outflow. Kobiór is located in Pszyczyński county, to the south of Katowice conurbation. It is a municipality of a significant proportion of wooded lands.

The process of suburbanization, as seen in the light of migration, is clearly visible in Wyry. They are located in Mikołowski county, in the direct vicinity of the core of metropolis. Since 2002 it has exhibited a permanent inflow of new dwellers and a positive migration balance. The migrations occur within the distance of $23 \mathrm{~km}$. In $2002-2015$ the migration balance fluctuated from 3.2\%o to $21.3 \%$. In the examined period, Wyry gained 2,361 new inhabitants, 2,081 from urban areas (26.6\%), principally from Silesia. The new dwellers originate from Tychy, Mikołów and Łaziska Górne. Certain activeness may be noticed among the inhabitants of the capital of the region, namely Katowice. The municipality of Wyry is well communicated by a network of roads with the surrounding urban areas, as well as is under a strong influence thereof, despite a relatively weak system of public transportation. In 2015, new dwellers constituted $30 \%$ of the total population of the municipality.

The last of the examined municipality is Gierałtowice located in the Gliwice county, in its southern part. This particular municipality experiences a constant inflow of population, whereas the factor of migration balance increased from $0.1 \%$ (2002) to $13.9 \%$ (2015). 2008 - 2012 are the years of the highest dynamics of increase. The municipality of Gierałtowice gained 2,400 new inhabitants in this period, predominantly from urban areas, on average 171 people per year. Most of the migrants originated from the urban areas located in the vicinity or within $15 \mathrm{~km}$. Former dwellers of Knurów, Zabrze, Gliwice and Ruda Śląska constitute a significant proportion of the population. The municipality is under a strong influence of the surrounding core cities of Górnośląsko-Zagłębiowska Metropolis.

Permanent migrations are inversely proportional to circular migrations. The labour market of the suburban area of Górnośląsko-Zagłębiowska Metropolis is strictly related to the core of the metropolis [17]. Katowice, as the central city and the biggest labour market, attracts workforce from the suburban area and other cities. It is also the principal labour centre for the examined rural municipalities. The proportion of departures for work constitutes $26-47 \%$. In total, the circular migrations of the eight studied municipalities came up to 3.8 thousand in $2011(21.3 \%)$, which is $8.4 \%$ of all departures for work in the suburban area. The second important labour centre is Gliwice located in the western part of Górnośląsko-Zagłębiowska Metropolis. It is similar for Tychy from the south and 
Tarnowskie Góry. This centre is not located in the core, nonetheless has strong influence in the northern part of the metropolitan area. To a lesser extent, other important labour markets in the examined municipalities are Mikołów and Będzin. The proportion of commuting in the aforementioned centres is on the level of $25-40 \%$ (Fig. 3).

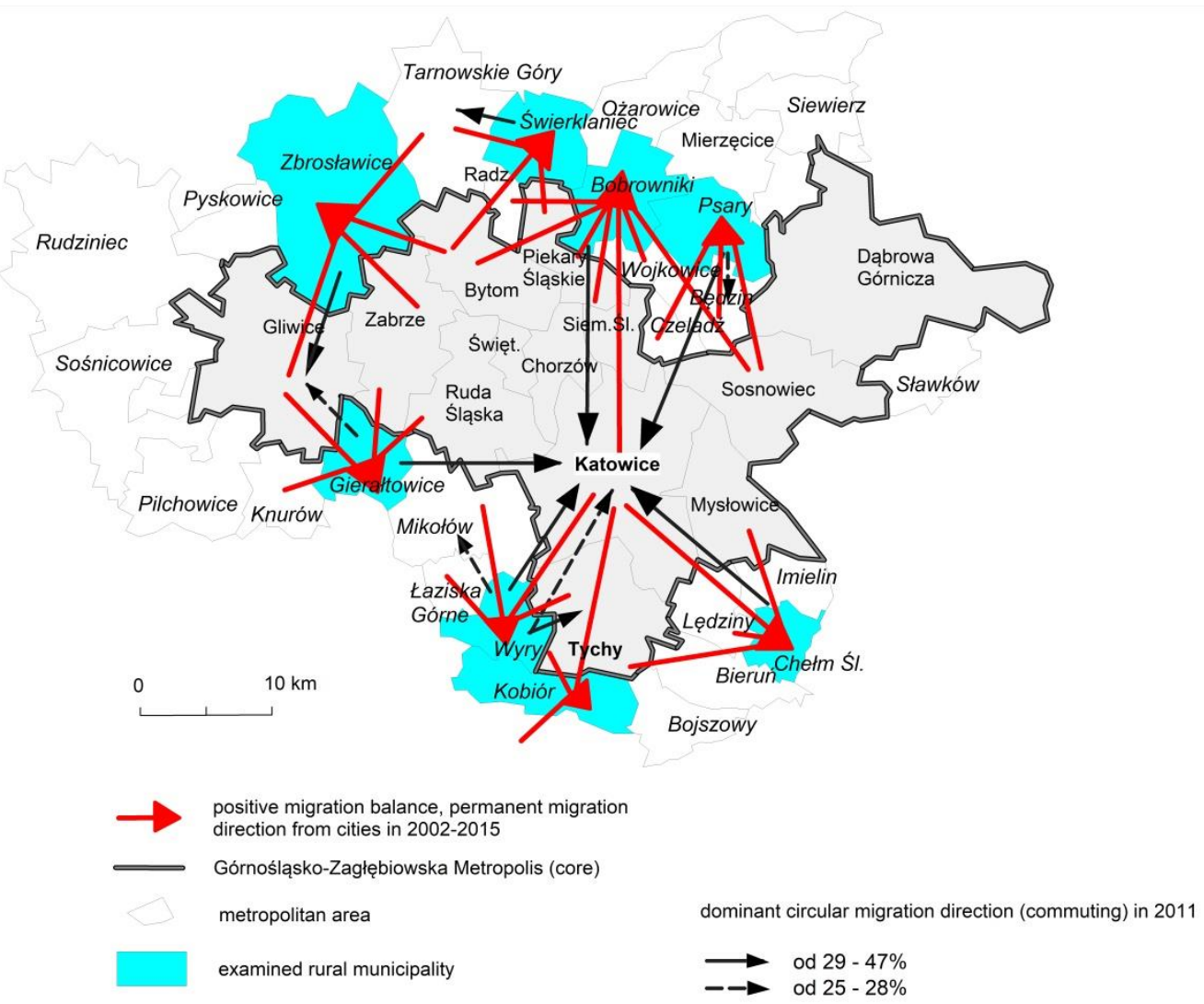

Figure 3. Permanent migrations from cities and circular migrations (commuting) in rural municipalities.

Taking into consideration commuting to work in four of the municipalities located to the north of the core, they constitute 1.9-2.3 thousand people. A characteristic feature thereof is a high diversification of departure directions, on average to 21 other municipalities (cities of different sizes: core cities, counties, small towns and other rural municipalities), as well as larger labour markets (2.8-4.8 thousand employees). On the other hand, in the southern municipalities commuting is done by $0.7-1.8$ thousand people, on average to 13 municipalities, whereas the labour markets have 1.6-2.4 thousand of employees.

\section{CONCLUSIONS}

Internal migrations in the examined area contribute to the increase of populations in rural areas, whereas new dwellers constitute a significant proportion of traditional theretofore communities. The scale and direction of migrations prove that the examined municipalities undergo suburbanization, which gives evidence to a more significant influence of the core of the metropolis, which leads to spatial metropolization. The origin of new inhabitants proves strong interrelations with major cities of the GZM core, as well as sheds new light on the directions of intra-regional migrations. It also presents new zones of inflow of the major centres. 
The examined rural municipalities recorded increases of inflows, and therefore positive migration balances, on average 175 people per year. Suburban areas located in the area of influence of major Silesian cities have become an attractive habitat for city dwellers, similarly to other parts of Poland. All of the examined municipalities undergo suburbanization processes. At the earliest they were exhibited in: Bobrowniki, Psary, Świerklaniec, Wyry and Gierałtowice. As compared to other metropolitan centres in Poland, the process is less visible in the background of Górnośląsko-Zagłębiowska Metropolis [26], [3], [22], which results from a whole spectrum of the socio-economic transformation of the nineties of the twentieth century.

Nevertheless, new inhabitants of the municipalities - the researched migrants of rural municipalities - contribute to the increase of population, whereas their participation in relation to indigenous dwellers on the level of $19 \%$ - 30\% results in the improvement of age- and profession-related structure of the population.

Migrations are related to the increase of development areas, which is an unfavourable phenomenon in the light of urban sprawl. Inhabitants erect detached houses, which manifests as the development of a residential function, causes a change of lifestyle and functional changes, but at the same time increases the expenditures on the infrastructure, as new roads, water pipes, sewage system, lighting, etc. [28], [12].

The municipalities under study are under a strong influence of large to medium cities of Górnośląsko-Zagłębiowska Metropolis: Bytom (Bobrowniki, Świerklaniec), Sosnowiec (Psary), Katowice (Bobrowniki, Chełm Śląski), Dąbrowa Górnicza (Psary), Tarnowskie Góry (Świerklaniec, Zbrosławice), Piekary Śląskie (Bobrowniki, Świerklaniec), Gliwice (Zbrosławice, Gierałtowice), Zabrze (Zbrosławice, Gierałtowice), Mysłowice (Chełm Śląski), Tychy (Kobiór, Wyry). It results from a relatively close vicinity (15 to $23 \mathrm{~km}$ ), a favourable location in terms of passageways, as well as commuting time (40 minutes with a passenger car).

The municipalities located to the south of the core are located in the area of influence of other cities than the ones located to the north, whereas suburbanization processes although occurring relatively early - are of a slighter slower dynamics. The biggest amount of new dwellers appeared in the municipalities located to the north of the metropolis. It results from a more favourable location, as well as a polycentric settlement system of conurbation type which, under the influence of the socio-economic transformation and globalization, develops into a metropolitan area. The polycentricity transforms into complex and overlapping areas of influence of certain core cities.

The attractiveness of the examined rural municipalities seems to result from different conditions. The municipality of Kobiór stands out from the discussed ones. It is located in the area of influence of one city only. Five out of eight municipalities are in the area of influence of three cities, Zbrosławice - four, whereas Chełm Śląski - two.

The newcomers fundamentally came from the cities of Silesia. Zbrosławice stands out from other municipalities in terms of the highest inflow and outflow, in absolute values. The same can be said about Kobiór, to a lesser extent. As per 1,000 inhabitants, the highest participation of migrants occurred in Wyry.

On the other hand, commuting exhibits new functional relations and determine the boundaries of daily urban systems. The examined municipalities reveal strong functional relations with the cities of the core, particularly with Katowice, as well as county cities and other small towns located in the neighbourhood. The majority of municipality is located within the daily urban system of Katowice, only one of them - in the daily urban system of Gliwice. Due to the polycentricity of Górnośląsko-Zagłębiowska Metropolis, 
the relations mentioned above exhibit the features of a network city. Rural areas located in the vicinity of the urban system of Górnośląsko-Zagłębiowska Metropolis undergo suburbanization processes and functional-spatial transformations. In the literature of the subject it has been numerously highlighted that a location against a large urban centre contributes to transformations of various types, which is time dependent. On one hand, rural areas in suburban zones undergo these changes more rapidly than peripheral lands. On the other hand, they utilize the so called location rent and are, to a certain degree, "stowaways" that utilize a better natural environment, lower taxes, prices of land, as well as expensive to maintain services of a higher order of the nearby metropolis.

\section{REFERENCES}

[1] Bański, J. Współczesne i przyszłe zmiany w strukturze przestrzennej obszarów wiejskich wybrane zagadnienia. [w:] pod red. Górz B., Guzik Cz., Współczesne przeobrażenia i przyszłość polskiej wsi, Studia Obszarów Wiejskich, PTG, Warszawa, vol. IV, pp 11-25, 2003.

[2] Demographic Yearbook of Poland 2016, Central Statistical Office, Warsaw.

[3] Gałka J., Kurek S., Wójtowicz M. Przestrzenne zróżnicowanie zmian zaludnienia w Krakowskim Obszarze Metropolitalnym w okresie 1988 - 2011, Studia Miejskie, Uniwersytet Opolski, Opole, pp 59 -77, 2013.

[4] Heffner K.Directions of Changes in the Development of Polish Rural Areas - Entering into European Rural Space [w:] ed. Kamińska W., Heffner K. Rural Development and EU Cohesion Policy, Committee for Spatial Economy and Regional Planning, Polish Academy of Sciences, "Studia Regionalia", Warsaw, vol. 39, pp 10-31, 2014.

[5] Kahrik A., Tammaru T. Population composition in new suburban settlements of the Tallin metropolitan area, Urban Studies, vol. 45 (5-6), pp 1055- 1078, 2008.

[6] Kovacs Z. A city at the crossroads: social and economic transformation in Budapest, Urban Studies, vol. 31 (7), pp 1081- 1096, 1994.

[7] Leetmaa K., Tammaru T. Suburbanization in Countries in Transition: Destinations of Suburbanizers, Geografiska Annaler, 89B, pp 127-146, 2007.

[8] Lisowski A. Social aspects of the suburbanization stage in the agglomeration of Warsaw, „Dela” 21, pp 531-541, 2004.

[9] Lisowski A. Urban sprawl process. In Urban sprawl -Warsaw Agglomeration Case Stud ed. Gutry-Korycka M., WUW, Warszawa, pp 83-99, 2005.

[10] Novak J., Sykora L. A city in motion: time-space activity and mobility patterns of suburban inhabitants and the structuration of the spatial organization of the prague metropolitan area, Geografiska Annaler: Series B, Human Geography, vol. 89 (2), pp 147-168, 2007.

[11] Ourednicek M. Differential Suburban Development in the Prague Urban Region. Geografiska Annaler, 89B, pp 111-126, 2007.

[12] Raźniak P., Winiarczyk-Raźniak A. Influence of the societal security level on population migrations in Poland, Procedia-Social and Behavioral Sciences, vol. 120, pp 2-12, 2014.

[13] Runge A. Procesy i struktury ludnościowe w województwie śląskim [w:] Runge J., Żurek I. (red.), Procesy i struktury demograficzno-społeczne na obszarze województwa śląskiego w latach 1988-2008, Urząd Statystyczny, Katowice, pp 33-82, 2010.

[14] Runge A. Medium size towns in complex settlement systems (exemplified by Katowice conurbation), "Problems of Geography", Bulgarian Academy of Sciences, Sofia, vol. 1-2, pp 49$65,2012$. 
[15] Runge A. Ludność województwa ślaskiego [w:] Kaczmarek R. (red.), Encyklopedia Województwa Śląskiego, wyd. Instytut Badań Regionalnych Biblioteki Śląskiej, Katowice, 2014.

[16] Runge A. Urban agglomerations and transformations of medium-sized towns in Poland, Environmental \& Socio-economic Studies, vol. 4, issue 3, pp 41-55, 2016.

[17] Sitek S., Zuzańska-Żyśko E. Small Towns in Metropolitan Silesia Region in the Context of Commuting to Work [w:] Kwiatek-Soltys A., Mainet H., Widermann K., Edouard J-C. (red.): Small and Medium Towns' Attractiveness at the beginning of the 21st Century, CERAMAC (Centre for Research on Massif Central, Mountains and Fragiles Territories), France, No. 33, pp 269-286, 2014.

[18] Spórna T., Kantor-Pietraga I., Krzysztofik R. Trajectories of depopulation and urban shrinkage in the Katowice Conurbation, Poland, Espace Populations Sociétés, Espaces en dépeuplement, 2015/3-2016/1, 2016.

[19] Sykora L. Changes in the Internal Spatial Structure of Post-communist Prague. GeoJournal, 49, pp 79-89, 1999.

[20] Szymańska D., Matczak A. Urbanization in Poland: tendencies and transformation, European Urban and Regional Studies, vol. 9 (1), pp 39- 46, 2002.

[21] Szymańska D., Bagińska J. Obszary podmiejskie dużych miast w Polsce w świetle migracji stałych [w:] Soja M., Zborowski A. (red.) Człowiek w przestrzeni zurbanizowanej, Instytut Geografii i Gospodarki Przestrzennej UJ, Kraków, pp 83 - 98, 2011.

[22] Śleszyński P. Procesy suburbanizacji w Polsce a polityka przestrzenna i regionalna. In Centra i peryferie w okresie transformacji ustrojowej, ed. A.Wolaniuk, XXIII Konwersatorium Wiedzy o Mieście, Wydawnictwo UŁ, Łódź, pp 11-26, 2014.

[23] Więcław-Michniewska J. Krakowskie suburbia i ich społeczność, IGiGP UJ, Kraków, pp 169, 2006.

[24] Raźniak P., Winiarczyk-Raźniak A. Spatial distribution and differences in migration patterns and revenues of gminas in the Kraków Metropolitan Area, Bulletin of Geography, SocioEconomic Series, No. 19, pp 73-86, 2013.

[25] Vaishar A., Zapletalova J. Sustainable development of the Moravian countryside, Journal of Geography, vol. 5-1, pp 43-54, 2010.

[26] Zborowski A. Przemiany struktury społeczno-przestrzennej regionu miejskiego w okresie realnego socjalizmu i transformacji ustrojowej (na przykładzie Karkowa), IGiPZ UJ, Kraków, pp 576, 2005.

[27] Zborowski A., Chaberko T., Kretowicz P. Procesy suburbanizacji rezydencjonalnej w regionie miejskim Krakowa: przemiany społeczno-przestrzenne [w:] Jakóbczyk-Gryszkiewicz J. (red.), Regiony miejskie w Polsce. Dwadzieścia lat transformacji, Wydawnictwo Uniwersytetu Łódzkiego, Łódź, pp 49-72, 2011.

[28] Zborowski A., Raźniak P. Suburbanizacja rezydencjonalna w Polsce-ocena procesu, Studia Miejskie, vol. 9, pp 37-50, 2013.

[29] Zuzańska-Żyśko E. Demographic potential of small towns of Silesian province in the last decade of 20th century, Biuletyn Geograficzny, UMK, Torun, No. 1, pp 159-166, 2002.

[30] Zuzańska-Żyśko E. Procesy metropolizacji. Teoria i praktyka, PWN, Warszawa, pp 432, 2016.

[31] Zuzańska-Żyśko E., Pytel S., Koman W. Suburbanization in Postindustrial Area. Case Study of The Silesia Metropolitan Region [w:] Efe R., Cürebal I., Lévai L. (red.), GeoMed 2016. $4^{\text {th }}$ International Geography Symposium. Book of Proceedings, Kemer, Antalya (Turkey), 835-849, 2016. 